\title{
Front Matter: Volume 8979
}

, "Front Matter: Volume 8979," Proc. SPIE 8979, Emerging Digital Micromirror Device Based Systems and Applications VI, 897901 (26 March 2014); doi: 10.1117/12.2063180

SPIE. Event: SPIE MOEMS-MEMS, 2014, San Francisco, California, United States 


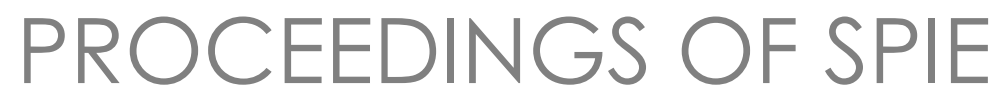

\title{
Emerging Digital Micromirror Device Based Systems and Applications VI
}

\author{
Michael R. Douglass \\ Philip S. King \\ Benjamin L. Lee \\ Editors
}

4-5 February 2014

San Francisco, California, United States

Sponsored by

SPIE

Cosponsored by

Samsung Advanced Institute of Technology (Korea, Republic of)

DLP Texas Instruments (United States)

Published by

SPIE 
The papers included in this volume were part of the technical conference cited on the cover and title page. Papers were selected and subject to review by the editors and conference program committee. Some conference presentations may not be available for publication. The papers published in these proceedings reflect the work and thoughts of the authors and are published herein as submitted. The publisher is not responsible for the validity of the information or for any outcomes resulting from reliance thereon.

Please use the following format to cite material from this book:

Author(s), "Title of Paper," in Emerging Digital Micromirror Device Based Systems and Applications VI, edited by Michael R. Douglass, Philip S. King, Benjamin L. Lee, Proceedings of SPIE Vol. 8979 (SPIE, Bellingham, WA, 2014) Article CID Number.

ISSN: 0277-786X

ISBN: 9780819498922

Published by

SPIE

P.O. Box 10, Bellingham, Washington 98227-0010 USA

Telephone +1 3606763290 (Pacific Time) · Fax +1 3606471445

SPIE.org

Copyright (@ 2014, Society of Photo-Optical Instrumentation Engineers.

Copying of material in this book for internal or personal use, or for the internal or personal use of specific clients, beyond the fair use provisions granted by the U.S. Copyright Law is authorized by SPIE subject to payment of copying fees. The Transactional Reporting Service base fee for this volume is $\$ 18.00$ per article (or portion thereof), which should be paid directly to the Copyright Clearance Center (CCC), 222 Rosewood Drive, Danvers, MA 01923. Payment may also be made electronically through CCC Online at copyright.com. Other copying for republication, resale, advertising or promotion, or any form of systematic or multiple reproduction of any material in this book is prohibited except with permission in writing from the publisher. The CCC fee code is 0277-786X/14/\$18.00.

Printed in the United States of America.

Publication of record for individual papers is online in the SPIE Digital Library.

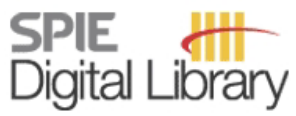

SPIEDigitallibrary.org

Paper Numbering: Proceedings of SPIE follow an e-First publication model, with papers published first online and then in print and on CD-ROM. Papers are published as they are submitted and meet publication criteria. A unique, consistent, permanent citation identifier (CID) number is assigned to each article at the time of the first publication. Utilization of CIDs allows articles to be fully citable as soon as they are published online, and connects the same identifier to all online, print, and electronic versions of the publication. SPIE uses a six-digit CID article numbering system in which:

- The first four digits correspond to the SPIE volume number.

- The last two digits indicate publication order within the volume using a Base 36 numbering

system employing both numerals and letters. These two-number sets start with 00, 01, 02, 03, 04, 05, 06, 07, 08, 09, 0A, 0B ... 0Z, followed by 10-1Z, 20-2Z, etc.

The CID Number appears on each page of the manuscript. The complete citation is used on the first page, and an abbreviated version on subsequent pages. Numbers in the index correspond to the last two digits of the six-digit CID Number. 


\section{Contents}

vii Conference Committee

BIOMEDICAL IMAGING WITH ADVANCED MICROSCOPY USING A DMD OR OTHER MEMS MICROMIRROR II: JOINT SESSION WITH CONFERENCES 8947 AND 8979

897903 The use of hyperspectral imaging (HSI) in wound healing (Invited Paper) [8979-21]

J. La Fontaine, L. Lavery, The Univ. of Texas Southwestern Medical Ctr. at Dallas (United

States); K. Zuzak, Digital Light Innovations (United States)

897904 DLP technology application: 3D head tracking and motion correction in medical brain imaging [8979-22]

O. V. Olesen, Technical Univ. of Denmark (Denmark), Rigshospitalet (Denmark), and Massachusetts General Hospital (United States); J. Wilm, Technical Univ. of Denmark (Denmark) and Rigshospitalet (Denmark); R. R. Paulsen, Technical Univ. of Denmark

(Denmark); L. Højgaard, Rigshospitalet (Denmark); R. Larsen, Technical Univ. of Denmark (Denmark)

897905 Using digital micromirror devices for focusing light through turbid media [8979-23]

S. N. Chandrasekaran, H. Ligtenberg, W. Steenbergen, I. M. Vellekoop, Univ. Twente (Netherlands)

\section{STRUCTURED LIGHT 3D IMAGING METHODOLOGY}

897907 Towards superfast 3D optical metrology with digital micromirror device (DMD) platforms [8979-1]

T. Bell, S. Zhang, lowa State Univ. (United States)

897908 Comparison of fixed-pattern and multiple-pattern structured light imaging systems [8979-2] V. Appia, P. Gelabert, Texas Instruments Inc. (United States)

897909 Accurate and simple calibration of DLP projector systems [8979-3]

J. Wilm, O. V. Olesen, Technical Univ. of Denmark (Denmark) and Rigshospitalet (Denmark);

R. Larsen, Technical Univ. of Denmark (Denmark)

\section{STRUCTURED LIGHT 3D IMAGING APPLICATIONS}

8979 OA Robust near-infrared structured light scanning for 3D human model reconstruction [8979-4] B. Fu, R. Yang, Univ. of Kentucky (United States)

8979 OB High-speed active head tracking system [8979-5]

V. Markov, S. A. Kupiec, Advanced Systems \& Technologies, Inc. (United States);

A. Hastings, U.S. Army Night Vision \& Electronic Sensors Directorate (United States); T. Hester, Advanced Systems \& Technologies, Inc. (United States) 
HOLOGRAPHIC AND SPECTROSCOPIC APPLICATIONS

8979 OC Microsecond reconfigurable NxN data-communication switch using DMD (Invited Paper) [8979-6]

P.-A. Blanche, A. Miles, B. Lynn, J. Wissinger, College of Optical Sciences, The Univ. of Arizona (United States); D. Carothers, College of Optical Sciences, The Univ. of Arizona (United States) and Texas Instruments Inc. (United States); R. A. Norwood,

N. Peyghambarian, College of Optical Sciences, The Univ. of Arizona (United States)

8979 OD Precise holograms using complex light modulation [8979-7]

J. Liang, Washington Univ. in St. Louis (United States) and The Univ. of Texas at Austin

(United States); M. F. Becker, The Univ. of Texas at Austin (United States)

8979 OE Micro-mirror arrays for spectroscopic applications [8979-8]

W. M. Duncan, C. J. Maxwell, The Univ. of Texas at Dallas (United States)

SYSTEM DESIGNS FOR EMERGING DMD APPLICATIONS

8979 OF DMDs for smart headlights (Invited Paper) [8979-25]

R. Tamburo, S. G. Narasimhan, A. Rowe, T. Kanade, Carnegie Mellon Univ. (United States):

E. Nurvitadhi, M. Chen, Intel Research Pittsburgh (United States)

8979 OG High resolution and energetically efficient lensless imaging system based upon time varied pinholes array (Invited Paper) [8979-9]

A. Schwarz, A. Shemer, Z. Zalevsky, Bar-llan Univ. (Israel)

$8979 \mathrm{OH} \quad$ Frequency division multiplexed imaging: a Texas Instruments DMD implementation [8979-10]

H. Habibkhani, Louisiana State Univ. (United States); B. K. Gunturk, Louisiana State Univ. (United States) and Istanbul Medipol Univ. (Turkey); M. Feldman, Louisiana State Univ.

(United States); A. U. Batur, Texas Instruments Inc. (United States)

8979 0l Use of high-radiant flux, high-resolution DMD light engines in industrial applications [8979-11]

A. Müller, In Vision (Austria); S. Ram, Lenzing Technik GmbH (Austria)

8979 0J Dynamically reconfigurable framework for pixel-level visible light communication projector [8979-12]

L. Zhou, S. Fukushima, T. Naemura, The Univ. of Tokyo (Japan)

\section{ADVANCED 3D DISPLAY}

8979 OK Design of a single projector multiview 3D display system [8979-13]

J. Geng, IEEE Intelligent Transportation Systems Society (United States)

8979 OM Precise control and animation creation over the DMD for projection-based applications [8979-15]

B. Koudsi, Optecks, LLC (United States) 
8979 ON A scalable multi-DLP pico-projector system for virtual reality [8979-16]

F. Teubl, Univ. de São Paulo (Brazil); C. Kurashima, Univ. Federal do ABC (Brazil); M. Cabral, Univ. de São Paulo (Brazil); S. Fels, Univ. of British Columbia (Canada); R. Lopes, M. Zuffo,

Univ. de São Paulo (Brazil)

897900 Integration of real-time 3D image acquisition and multiview 3D display [8979-17]

Z. Zhang, Z. Geng, T. Li, Institute of Automation (China); W. Li, J. Wang, Y. Liu, Nanjing Univ. of Aeronautics and Astronautics (China)

Author Index 
Proc. of SPIE Vol. $8979897901-6$

Downloaded From: https://www.spiedigitallibrary.org/conference-proceedings-of-spie on 26 Apr 2023 Terms of Use: https://www.spiedigitallibrary.org/terms-of-use 


\title{
Conference Committee
}

\author{
Symposium Chair
}

David L. Dickensheets, Montana State University (United States)

Symposium Co-chair

Holger Becker, microfluidic ChipShop GmbH (Germany)

\section{Conference Chairs}

Michael R. Douglass, Texas Instruments Inc. (United States)

Philip S. King, Texas Instruments Inc. (United States)

Benjamin L. Lee, Texas Instruments Inc. (United States)

\section{Conference Program Committee}

Umit Batur, Texas Instruments Inc. (United States)

Hal Bellis, Keynote Technologies, LLC (United States)

Sara L. Best, University of Wisconsin School of Medicine and Public Health (United States)

Daniel N. Carothers, Consultant (United States)

Goksel Dedeoglu, Texas Instruments Inc. (United States)

Jason Geng, Xigen, LLC (United States)

Roland Höfling, ViALUX GmbH (Germany)

Alfred Jacobsen, Visitech AS (Norway)

Yuval Kapellner Rabinovitz, EKB Technologies Ltd. (Israel)

Yongzhi Charley Yang, Wintech Digital Systems Technology

Corporation (United States)

Karel J. Zuzak, Digital Light Innovations (United States)

\section{Session Chairs}

1 Biomedical Imaging with Advanced Microscopy using a DMD

or Other MEMS Micromirror I: Joint Session with Conferences 8947 and 8979

Karel J. Zuzak, Digital Light Innovations (United States)

Robert C. Leif, Newport Instruments (United States)

2 Biomedical Imaging with Advanced Microscopy using a DMD or other MEMS Micromirror II: Joint Session with Conferences 8947 and 8979

Karel J. Zuzak, Digital Light Innovations (United States)

Fartash Vasefi, SMI (United States) 
3 Structured Light 3D Imaging Methodology

Benjamin L. Lee, Texas Instruments Inc. (United States)

Jason Geng, Xigen, LLC (United States)

4 Structured Light 3D Imaging Applications

Benjamin L. Lee, Texas Instruments Inc. (United States)

Roland Höfling, ViALUX GmbH (Germany)

5 Holographic and Spectroscopic Applications

Daniel N. Carothers, Consultant (United States)

Philip S. King, Texas Instruments Inc. (United States)

6 System Designs for Emerging DMD Applications

Yuval Kapellner Rabinovitz, EKB Technologies Ltd. (Israel)

Goksel Dedeoglu, Texas Instruments Inc. (United States)

7 Advanced 3D Display

Philip S. King, Texas Instruments Inc. (United States)

Michael R. Douglass, Texas Instruments Inc. (United States) 